UDC 271.2(477.8):002.2“17"

DOI: $10.24919 / 2519-058 x .15 .204969$

\begin{abstract}
Svitlana KAGAMLYK
PhD (History), Senior Researcher of the Ukrainian Studies Center, Faculty of Philosophy, Taras Shevchenko Kyiv National University, 64/13 Volodymyrska Street, Kyiv, Ukraine, postal code01601(kagam@i.ua)
\end{abstract}

ORCID: https://orcid.org/0000-0003-4732-1410

ResearcherID: W-7411-2019

\title{
Світлана КАГАМЛИК
}

кандидат історичних наук, стариий науковий співробітник, стариий науковий співробітник Центру українознавства філософського факультету Київського національного університету імені Тараса Шевченка, вул. Володимирська 64/13, м. Київ, Україна, індекс01601 (kagam@i.uа)

Бібліографічний опис статті: Kagamlyk, S. (2020). How Moscow colonized KyivPechersk Lavra. New pages to the history of the Ukrainian printing of the second half of the XVIIIth century. Skhidnoievropeiskyi Istorychnyi Visnyk [East European Historical Bulletin], 15, 54-64. doi: 10.24919/2519-058x.15.204969

\section{HOW MOSCOW COLONIZED KYIV-PECHERSK LAVRA. NEW PAGES TO THE HISTORY OF THE UKRAINIAN PRINTING OF THE SECOND HALF OF THE XVIIIth CENTURY}

\begin{abstract}
The purpose of the article - on the basis of newly discovered archival materials, to analyze the complex conditions of book publishing activity of Kyiv-Pechersk Lavra of the second half of the XVIIIth century under pressure from the censorship of the Russian imperial authorities, which led to the ultimate loss of independence of Lavra printing press. The Novelty of the Research. The main source of the research is a non-updated correspondence of the special authorized persons from Lavra monastic fraternity with the rector of Pechersk monastery, who were entrusted with various important cases of a legal, economic, educational character, in particular, to assert the independence of Pechersk printing. The Methodology of the Research. In the article the method of intellectual networks modelling, which gives an opportunity to look at the Ukrainian cultural world as a structure of intellectual networks, has been used on the materials of the correspondence. The Conclusions. Thus, the newly discovered archival materials attest to the censorship of the Russian imperial power, which sought to deprive finally Kyiv-Pechersk Lavra of its opposition and originality in book publishing. In order to preserve the ancient freedom of the press, the monastery's management sent to the capital cities of the Russian Empire special authorized persons, who performed the functions of monastic lawyers. The letters of Lavra commissioners to Pechersk Archimandrite Zosym Valkevych attest to their efforts to defend the independence of Lavra printing, in which, however, they could not succeed under conditions of the Russian centralism under the rule of Catherine II. By the act of secularization of the monastery lands in 1786, Kyiv-Pechersk Lavra was subordinated to the direct care of the Metropolitan of Kyiv, to whom the Synod transferred all control over printing in Lavra printing house. In this way, Lavra lost its main right of stauropegia, and Pechersk printing house finally lost its independence in book publishing.

Key words: Orthodox Church, Kyiv-Pechersk Lavra, Ukrainian printing, Pechersk printing house, Russian imperial power.
\end{abstract}




\title{
ЯК МОСКВА КОЛОНІЗУВАЛА КИЕВО-ПЕЧЕРСЬКУ ЛАВРУ. НОВІ СТОРІНКИ ДО ІСТОРІЇ УКРАЇНСЬКОГО ДРУКАРСТВА ДРУГОї ПОЛОВИНИ ХVIII СТ.
}

\begin{abstract}
Анотація. Мета дослідження: У статті ставиться за мету проаналізувати складні умови книговидавничої діяльності Києво-Печерської лаври другої половини ХVIII cm. під тиском цензури російської імперської влади, щуо призвело до остаточної втрати незалежності лаврського друкарства. Джерела і новизна: Головним джерелом дослідження є неактуалізоване листування з настоятелем Печерського монастиря спеціальних уповноважених осіб із лаврської чернечої братії, яким доручалися різні важливі справи юридичного, господарського, просвітницького та іншого характеру, зокрема, відстоювання незалежності печерського друкарства. Методологія: У статті на матеріалах листування застосовано метод моделювання інтелектуальних мереж, який дає можливість поглянути на украӥнський культурний світ як структуру інтелектуальних мереж. Висновки. Нововиявлені архівні матеріали ЦДІАК України засвідчують иеезурні утиски російських властей, які намагалися остаточно позбавити Києво-Печерську лавру ії опозичійності та самобутності у книговидавничій діяльності. Наведені листи лаврських повірених до Печерського архімандрита Зосими Валькевича ілюструють їхні зусилля відстояти незалежність лаврського книгодрукування, які, проте, не могли досягти успіху в умовах російського ичентралізму за правління Катерини II. Попередження про небезпеку, щзо нависла над Києво-Печерською лаврою з ї̈ друкарнею, які звучали у листах лаврських повірених, були цілком резонні. Актом секуляризації монастирських земель 1786 р. Києво-Печерська лавра була підпорядкована безпосередньому догляду Київького митрополита, на якого Синод переклав весь контроль над видавництвом Лаврської друкарні. Тим самим Лавра позбулася свого головного права ставропігії, а Печерська друкарня остаточно втратила самостійність у книговидавничій діяльності.
\end{abstract}

Ключові слова: Православна Церква, Києво-Печерська лавра, украӥнське друкарство, Печерська друкарня, російська імперська влада.

The Problem Statement. During the 1990-ies, the first decade of the XXIst century a number of scientific studies appeared in the history science, illustrating various spheres of the Orthodox Church activity in Ukraine - church political, spiritual religious, cultural educational; the works that focus on the activity of both individual institutions and church biography. One of the most topical in this area there was the problem of defending the rights and interests of the Orthodox Church in connection with the subordination of Kyiv Metropolitanate to Moscow Patriarchate in 1686, which gains a special topicality nowadays in the context of the Russian military and information aggression. The materials of Kyiv-Pechersk Lavra Fund, which testify to the tense conditions of Pechersk printing house under conditions of the onset of the Russian centralism, are illustrated in this context.

The Analysis of Recent Researches and Publications. The history of Ukrainian printing, including book printing in Kyiv-Pechersk Lavra, thanks to the works of P. Trotsky, F. Titov, S. Maslov, I. Kahanov, I. Ohienko, J. Isaievych, D. Stepovyk and other scientists, belongs to the sphere of well-studied aspects of a national culture (Trotsky, 1865; Titov, 1916; Maslov, 1925; Kahanov, 1959; Ohienko, 1994; Stepovyk, 2001; Isaievych, 2002). Describing the complex conditions of Pechersk printing house in the XVIIIth century, the researchers mainly singled out the notorious decree of 1720 of Peter I, which deprived KievPechersk Lavra of the ancient freedom of the press. Less attention was paid to these works during the second half of the XVIIIth century, when after the favourable reign of Empress Elizabeth for Ukraine, there came the reign of Catherine II, a fatal one in all respects for the Ukrainian statehood and the Church. 
A thorough analysis of Kyiv-Pechersk Lavra Fund materials in the process of preparation a personal monograph by the author of this article on the history of a cultural and educational activity of the monastery of the XVIIth - XVIIIth centuries gave reason to think that in this sphere there will no longer be something unexpected (Kagamlyk, 2005). However, in the course of further work with the Fund materials on other studies, interesting documents were found out, which reveal the problems that arose in the activity of Pechersk printing press in the 60 -ies - in the early 70 -ies of the XVIIIth century.

The purpose of the article - on the basis of newly discovered archival materials, to analyze the complex conditions of book publishing activity of Kyiv-Pechersk Lavra of the second half of the XVIIIth century under pressure from the censorship of the Russian imperial authorities, which led to the ultimate loss of independence of Lavra printing press.

The Statement of the Basic Material. Unique in volume (more than 30000 cases, which exceeds the volume of the rest of the monastic foundations of the CSIAK of Ukraine taken totally), unique in a structural construction (11 separate structural units) and multifaceted information Kyiv-Pechersk Lavra Fund materials were researched, although fragmentally, by F. Titov, D. Vyshnevsky, P. Trotsky, Yu. Lebedyntsev, P. Zholtovsky, V. Shydenko, V. Mordvintsev during various periods of time. At the same time, a considerable layer of documents remained beyond the researchers' attention. It concerns the printing part of the fund, which, in addition to well-researched materials on the organization of printing production in the monastery, the circumstances of individual publications printing, the forms of their distribution, etc., postponed the correspondence of ecclesiastical figures from KyivPechersk Lavra fraternity, became the main source, used by us in this article.

In one of the latest author's publications, the importance of a thorough study of the epistolary heritage of Ukrainian ecclesiastical elite of the XVIIth - XVIIIth centuries was emphasized. The epistolary heritage of Ukrainian ecclesiastical elite of the XVIIth XVIIIth centuries reveals the diversity of cultural relationships and the peculiarities of functioning of "mohylianskoho intellectual space" (Kagamlyk, 2018).

It is worth noting that, using the method of intellectual networks modelling, which gives an opportunity to look at the Ukrainian cultural world as a structure of intellectual networks, modern researchers developed the idea of intellectual communities functioning as a means of legitimizing the cultural history of Ukraine (Kolesnyk, 2008). In particular, L. Posokova adapted this method to the activity of the Orthodox colleges as separate intellectual units (Posokhova, 2011). Similarly, this method can be applied to Kyiv-Pechersk Lavra as a separate intellectual environment, on the basis of which the Ukrainian church and secular elite united (Kagamlyk, 2006). According to our observations, one-third of the bishops and abbots of the Ukrainian and Russian monasteries finished the monastic ascension school in Kyiv-Pechersk Lavra (Kagamlyk, 2005, pp. 166-168). Taking advantage of its high status, the dignitaries of Kyiv-Pechersk Lavra fraternity favoured their native monastery in solving its particular issues, including those, related to publishing activity.

This article deals with the correspondence of special authorized persons who, after their monastic celibacy in Kyiv-Pechersk Lavra, reached certain administrative positions in the monastery or outside it. These persons, named in the documents by Lavra representatives, actually performed the functions of monastic attorneys in the territory of the metropolitan cities of the Russian Empire, who were entrusted with various important cases of a legal, economic, educational character, in particular, to defend the independence of Pechersk publishing, or at least easing the pressure of Moscow censorship. 


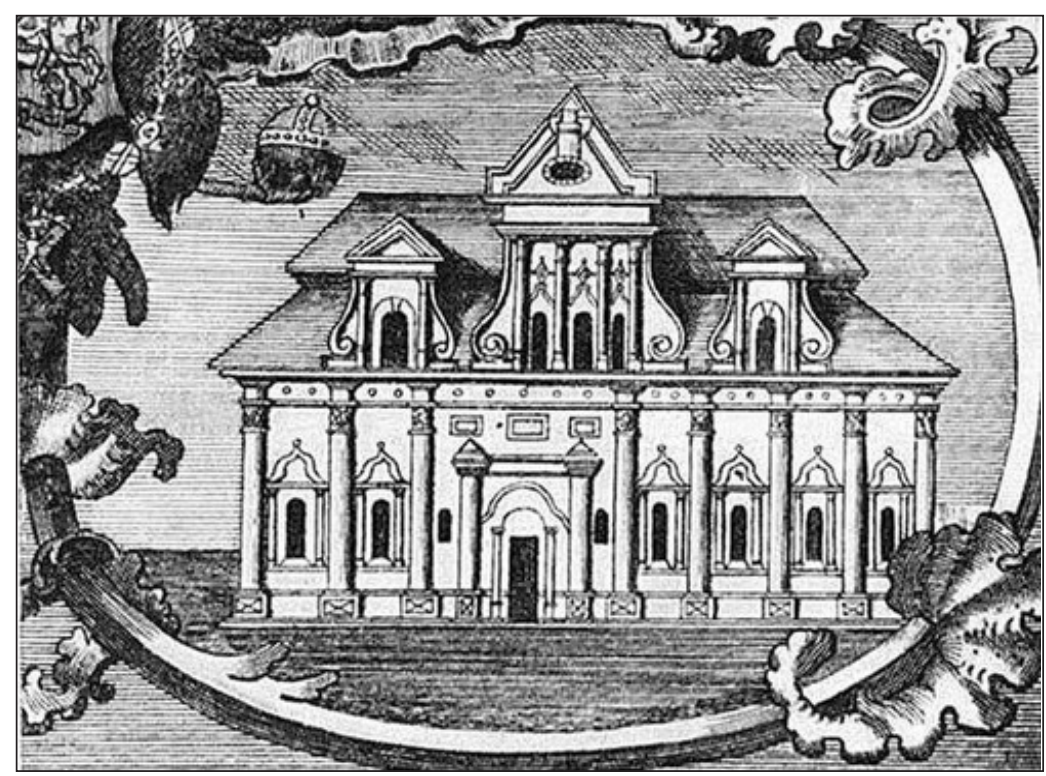

Printing House of Kyiv-Pechersk Lavra. Engraving of 1758.

We outline briefly the prerequisites for the processes discussed in this publication. With the subordination of Lavra to Moscow Patriarch on stauropegia rights in 1688, the issue of freedom of the press of Pechersk printing was raised. The imperial diploma for stauropegia demanded that Lavra should have mentioned the tsar and the patriarch in the printed books (Bolhovitinov, 1826, p. 224).

Formally agreeing to send the book to the patriarch for a previous review, Lavra in its printing activities tried to avoid a clerical censorship. Meletius Vuyakhevych, Pechersk Archimandrite, using the influential support of Hetman Ivan Mazepa, openly defended Lavra's independence in printing. In 1692, without the consent of Patriarch, the Liturgy text book was printed, in the preface of which, Lavra did not specify the names of Moscow tsars and Patriarch Adrian. This fact caused a violent dissatisfaction of Patriarch Adrian (Arhiv Yugo-Zapadnoi Rossii, 1872, p. 359; Ohienko, 1994, p. 289). In response, Meletius Vuyakhevych, stating that printing gives Lavra a basic income, requested Moscow Patriarch for permission to continue printing books without a prior consideration and review. However, the top Russian hierarch, although he apologized Meletius's “omission”, still insisted on agreeing with him printing of all the books in Lavra (Kagamlyk, 2005, p. 203).

Released on October 5, in 1720 Decree of Peter I caused a number of restrictions on Lavra, which previously enjoyed the freedom of printing. The requirements of the Russian authorities - a full correspondence with the books of the Russian press, obtaining permission to print each individual book, sending signal copies of books for a preliminary consideration of the Synod - made it necessary for the administration of the monastery to choose special authorized persons, whose activities were to be directed to facilitate the control over Lavra printing.

In December 1726, Lavra authorities asked the Synod for permission to print books "at the request of Malorosiyskoho and foreign Orthodox peoples" for a pray in a cell. In response, 
the Synod reminded of the need for a full correspondence of the press with similar Russian editions and demanded two copies of the newly printed editions (Central State Historical Archive of Ukraine in Kyiv - CSHAUK, f. 128, d. 1 drukarskyi, c. 6, p. 2). Therefore, in 1727 Lavra's authorities sent to St. Petersburg a special commissioner - Isaiah, a Hieromonk of Trubchevsky Cholnsky Monastery, instructing him to seek for easing the control over Lavra printing. Lavra's commissioner presented 2 copies of the newly published "New Testament" in 1725 to the Synod and requested for the approval of the book for sale. The petition of Lavra's representative was successful: the Synod, by decree of November 29, 1727, allowed the sale of this and other books printed in accordance with Moscow models, taking into account the fact that the Synod had no unnecessary troubles, and the monastery - unnecessary expenses and troubles (Opisanie dokumentov i del, 1885, № 327). The responsibility for printing books was entrusted to Pechersk Archimandrite, who had to check the newly printed books thoroughly (CSHAUK, f. 128, d. 1 drukarskyi, c. 105, p. 3).

Next year, in 1728, another commissioner - Lavra's governor, Roman Copa, applied for permission to print and sell books by Lavra that had previously been published in Pechersk printing house and had no Moscow analogues, such as the Prayer books and Akathists, which had been published in Kyiv (Opisanie dokumentov i del, 1885, № 327). In response to this petition, Decree of the Synod of February 21, 1728 was issued, which allowed to print these books on condition that there were no "oppositions" in them (CSHAUK, f. 128, d. 1 drukarskyi, c. 105, p. 4; Opisanie dokumentov i del, 1885, № 327). Thus, Lavra commissioners succeeded in their work - they managed to achieve censorship relief over the book publishing of Pechersk printing house, though temporarily.

However, with the reign of Catherine II, new pressures began on the language and spelling peculiarities of Lavra book publishing. On November 6, 1766 the Synod, noting that since 1728 Kyiv and Chernihiv printing houses did not send any books for the review, forbade printing of any new books, and previous editions always had to be checked with the Russian ones to eliminate any language differences (CSHAUK, f. 128, d. 1 drukarskyi, c. 105, p. 2). After the publication of "The New Testament" book, the Russian authorities were instructed to send to the Synod a register of books, printed in Pechersk printing house, indicating the time of publication, who allowed to print a book, and to submit the copies of the books. This threatened the printing press with a ban on the sale of these books and could cause large losses. Therefore, Lavra authorities decided to involve several commissioners in this case. Thus, in March 1767, Antony Sumnetsky, was sent to Moscow with a command mainly to seek for some relief from the censorship of Lavra printing, though he was also charged with solving other matters (CSHAUK, f. 128, d. 1 drukarskyi, c. 105, pp. 86-88). In the letter, dated from April 12, 1767, A. Sumnetsky reported that the employees of Moscow synodal printing house reviewed the books, printed in Lavra, with a special attention, "with passion" (CSHAUK, f. 128, d. 1 drukarskyi, c. 105, pp. 115-115 ret.). In another letter he added that the case could not be changed for the better (CSHAUK, f. 128, d.1 drukarskyi, c. 105, p. 119). Another commissioner Iov, a hieromonk, was instructed by Spiritual assembly of Kyiv-Pechersk Lavra to provide information on the possible decision of the Synod in this case (CSHAUK, f. 128, d. 1 drukarskyi, c. 108, p. 15). Despite the unfavourable circumstances and the worsening attitude towards Lavra by the members of the Synod, in which there were virtually no Ukrainians, the commissioners facilitated the adoption of the decree, which authorized the sale of books that were blacklisted, but on condition to continue printing these and other books, which were not published in Moscow printing house, as if the books had 
been previously published. Thus, dissatisfaction of Moscow authorities was mainly due to the fact that Lavra tried to avoid censorship and represented the publication of new books in the guise of reprinting the old ones, which was revealed by the synodal reviewers.

Despite the active activity of Lavra commissioners, the "black clouds" over Pechersk printing house became even more dense. In 1767, the Synod found "errors" (differences from Moscow analogues) in the newly published by Lavra "Oktoikh" and "Psalms" (CSHAUK, f. 128 , d. 1 drukarskyi, c. 108, 109; RSHA, f. 796, d. 48, c. 545; Opisanie dokumentov i del, 1915, № 191). In 1769, the "defective" were the publication of "The Six Days" and "The Bible", which resulted in a new decree of the Synod with threats of fine and increase in the number of reviewers of printing samples (CSHAUK, f. 128, d.1 drukarskyi, c. 161). In this regard, in January 1770, Zosyma Valkevych, Pechersk Archimandrite, appealed to Lavra commissioner in Moscow, Joseph Tymoshevych, Archimandrite of Moscow Zlatoust Monastery, so that he would investigate the situation concerning Lavra printings and send the copies of the correspondent documents to protect Lavra from possible troubles. In response, J. Tymoshevych wrote that he had made every effort to fulfill this request, but because "the discrepancies were written out in over two hundred notebooks", he only partially succeeded in writing out "the errors" from "The Six Days", which he managed to identify with great effort (CSHAUK, f. 128, d. 1 drukarskyi, c. 161, pp. 4-5).

Another commissioner of Kyiv-Pechersk Lavra, Varlaam Baranovych, who in 1772 substituted J. Tymoshevych as a rector of Moscow Zlatoust Monastery, was also involved in easing the control of Lavra book publishing. In his letter to Lavra of July 30, 1772 it is shown that, on behalf of the Spiritual assembly, he had to make an acquaintance with A. I. Pelsky, the director of Moscow synodal printing office, in order to speed up the review of Lavra books (CSHAUK, f. 128, d. 1 zagalnyi, c. 350, pp. 12-13).

How difficult the situation was at that time for Kyiv-Pechersk Lavra and the activities of its commissioners it is evidenced with the letter dated February 18, 1770, from one of them, Ahhei Kolosovsky, who was appointed the legislator of the Naval Noble Corps in St. Petersburg. Noting that the "mistakes", made in the Bible printing, were very dangerous for Lavra at that time, Lavra commissioner informed Archimandrite Zosym Valkevych that in this connection Archbishop of Moscow and Sevsky and a member of the Synod of the Russians, Platon Levshin, "had a quarrel with him". In particular, the bishop mentioned that he had found 468 mistakes in the Bible, which he marked personally, and that the monks of Lavra should be "punished well" for being warned repeatedly, but they "intentionally printed texts different from Moscow copies" (CSHAUK, f. 128, d. 1 drukarskyi, c. 161, p. 10).

The warnings of the danger that hung over Kyiv-Pechersk Lavra with its printing house, which sounded in the letters of Lavra's commissioners, were quite reasonable. Empress Catherine II, when preparing the act of secularization, intended to sweep away the Ukrainian Orthodox Church. The endless series of censorship decrees of the Synod lasted until 1786. Thus, in 1775, the Synod ordered Lavra to pay the employees of Moscow synodal printing house for checking the books, printed in Lavra, and beginning with 1783 - to send the information of the printed books annually (Kagamlyk, 2005, p. 214).

The censorship pressure concerning Pechersk publishing also affected the fate of Lavra's rector Zosym Valkevych, who, with the help of his proxies, consistently fought for the independence of Lavra printing. After the secularization of the monastery lands (1786) and the conversion of Lavra into a regular monastery, Zosym Valkevych was deprived of his duties as the abbot and sent to Holosiivska Pustyn' - a third-class monastery, where he was 
given a direct leadership. The last freely elected Pechersk Archimandrite "died in Holosiiv Pustyn' being fired because of blindness" (Kagamlyk, 2005, p. 295).

By the act of 1786, Kyiv-Pechersk Lavra was subordinated to the direct care of Samuel Myslavsky, Kyiv Metropolitan, who at the same time became its rector in the rank of archimandrite. He was entrusted with a direct care of Pechersk printing house. As a result, Lavra lost its primary right of stauropegia, and Pechersk printing house finally lost its independence in book publishing. According to I. Ohienko, "the old All-Ukrainian Academy, which worked so vigorously for the spiritual benefit of its people", gradually became a branch of Moscow synodal printing house (Ohienko, 1994, p. 311).

The Conclusions. Thus, the newly discovered archival materials attest to the censorship of the Russian imperial power, which sought to deprive finally Kyiv-Pechersk Lavra of its opposition and originality in book publishing. In order to preserve the ancient freedom of the press, the monastery's management sent to the capital cities of the Russian Empire special authorized persons, who performed the functions of monastic lawyers. The letters of Lavra commissioners to Pechersk Archimandrite Zosym Valkevych attest to their efforts to defend the independence of Lavra printing, in which, however, they could not succeed under conditions of the Russian centralism under the rule of Catherine II.

By the act of secularization of the monastery lands in 1786, Kyiv-Pechersk Lavra was subordinated to the direct care of the Metropolitan of Kyiv, to whom the Synod transferred all control over printing in Lavra printing house. In this way, Lavra lost its main right of stauropegia, and Pechersk printing house finally lost its independence in book publishing.

Acknowledgments. The authors sincere gratitude to all members of the editorial board for consultations provided during the preparation of the article for printing.

Funding. The authors received no financial support for the research and publication of this article.

\section{7 р., 12 квітня, м. Москва. - Лист блюстителя Ближніх печер Антонія Сумнецького до Печерського архімандрита Зосими Валкевича у справі цензури лаврського друку}

Ясне в Богу высокопреподобньйшій господине, высокомилостивій господине отче и пастырю!

Три ордеры, марта от 24 з Лавры отпущенніе, сего априля 6 числа чрез кіевского рейтарина Клименова мною получены, на которіе в покорности моей доношу: По 1-му: газеты, каковы сего года вышли, всђ оніе при сем посилаются, а чтоб в сей год в Лавру отпущены были, для того в здешней книжной лавкъ я записался. По 2-му: о Іпатіевских денгах возможно старателство прилагается и коллегія услужить желает, да просто не отваживается, а сискует благопристойных мър потерпђть до времени совътует. По 3-му: вседушно раднђйшій бы я в удоволствіе святой Лавры полную, как прошеніе гласит, о книгах резолюцію получить, да что дълать, книжніе немаліе погрђшности способы заграждают, смотрђть ужас ошибки каковы. Святьйшій Синод опредъленіе учинил, что печатать против московских книги, по оному и исполненіе навсегда чинить повельвает, а виступив с опредъленія оного ниже думает, милость несказанна, что не штрафуют, да прежніе продавать не дозволяют, а прозбу, чтоб по прежнему печатать, и слишать не хотят, дозволеніе дают какіе хотя величиною книги печатаются болшіе, средніе, маліе, или меншіе, да токмо в оних то класть, что 
в осковскіх болших либо малых положено, а что в оних ньт, то отнюдь не вносить, для того те лаврскіе книги [арк. 119 зв.] против московского пересльдовать и велено, что б по тому пересльдованію что явится сверхное и в московских небывалое выбросить. И сего синодалного намъренія да и учиненного уже опредъленія переломить отнюдь невозможно. Пересльдованіе оное книг продолжится, как з обстоятелств видно, немалое время может, и чтоб мнђ напрасно не изживатся великоновгородскій преосвященній в сходство імъемой быть по смотру резолюціи при партикулярном своем писменном видъ в Лавру отпущает, с коим отпуском по просухи по его вельнію я і віехать намърен, на что и вашой святынъ пастырского благословенія прошу. Сего априля 11 числа еще тры ордеры получил я з лавры марта от 7 дня пущенніе, причем ящик заидок в дванадцати неболших слойках принял, и на оніе доношу нижайше: 1. В трастную среду з отцем духовником по литургіи Ея імператорскому величеству и Его высочеству я был представлен, поздравленіе ему учинил и при том воскресніе канонники поднесл, за что ея величество и его высочество удоволствій свій оказати соизволили. 2. Інокентіевы непорядочніи поступки и противности великоновгородскому преосвященному мною доволно внушены, изволил сказать то ж, что и в Лаврђ об нем опредълено, сослать на комору в приписній какой монастырь, а іменно виговорил Омбишскій, [арк. 120] а когда он оттоль побежит, нужди ньт, буди сюда явится, то де похватится, его непорядочства и воровство въдает. 3. О Владимирской церквђ, что не строить и парохію к Вознесенской по прежнему причислить в воль де отца архимандрита состоит, а чаятелно, что і парохіане о устройки новой церкви усиливат не станут. 4. Синіе краски должен буду купить и з собою привезти імъю, а нинъ высокоотческой пастирской милости препоручив себя остаюсь

Ясне в Богу высокопреподобія Вашего высокомилостивого господина отца и пастиря всепокорнъйшій послушник іеромонах Антоній

Априля 121767 года

Москва.

Central State Historical Archive of Ukraine in Kyiv, f. 128, d.1 drukarskyi, c. 105, pp. 119-120.

\begin{abstract}
1770 р., січня 31, м. Москва. - Лист адвоката Кисво-Печерської лаври, архімандрита Московського Златоустівського монастиря Йосифа Тимошевича до Печерського архімандрита Зосими Валкевича у справі цензури лаврського друку

Высокопреподобньйшій господин мой архимандрить!

Писаніе Вашего высокопреподобія получил я сего генваря 21 дня пріятно, в коем предписывая мнђ справится о происходящем за типографскіе ошибки сльдствіи, изволите напоминать, дабы я, естли тяжелые окажутся ошибки, прилагал старателство и не допустил, чтоб на Лавру что-либо наведено было в Святъйшій Синод предосудителное. И как Вашему высокопреподобію извђстно, что я в исправленіи всьх поручаемых мнъ от Лавры комиссій ревностное и усердное по любви своей прилагал всегда старателство, то и в нынЊшнем случаи истощил всь средства, однако по важности дъла пособить никоим образом не можно, ибо чтоб остановить дъло и уничтожить уже выписанные на бумагу в великом множествђ ошибки, которые сами по себђ весма важны, и которые содержатся в присутственном мъстђ под крђпким храненіем, того учинить как господин директор, так и присутствующіи не могут и не имЂют в том
\end{abstract}


никакой власти; да и со всъм моим старателством не мог я от присутствующих, которые суть и пріятели мои, и спросить того, чтоб оные ошибки мнъ были и показаны, а обявлен толко мнђ указ Святьйшаго Синода, по которому дълается изсльдованіе и почти уже приведено ко окончанію и упователно в скорости будет в Святьйшій Синод отослано. Я по искренности моей Вашему высокопреподобію представляю, что сіе по важности своей не толко касается вообще [арк. 4 зв.] до Лавры, но и до нъкоторых за несмотреніе персон, а дабы Ваше высокопреподобіе могли в том удостовђриться, то сообщаю при сем с одного того Шестодневника выписанныя ошибки, которые я достал с великою нуждою и тайностію. Из оных, а особливо из касающихся до титула, можете Ваше высокопреподобіе усмотрьть, какое сіе дъло требует от вас вниманія и старанія. В дополненіе ж того слышно, что таких же несходств выписано болше двух сот тетрадей из привезенных отцем Антоніем Сумнъцким книг, из коих и инние по давности льт одной толко Лаврђ вообще, а инніе новЂйшіе и персонално могут быть опасны, впротчем одно благоразсужденіе Вашего высокопреподобія со всьм обществом да отвратит всякое нещастіе. А я со усердіем моим и истинным высокопочитаніем пребываю

Вашего высокопреподобія, милостиваго моего господина, отца і благодњтеля покорній слуга Іосиф, архимандрит Златоустовскій

Генваря 31 дня 1770 года.

Из Москвы.

Central State Historical Archive of Ukraine in Kyiv, f. 128, d.1 drukarskyi, c. 161, pp. 4-5. The Original.

1770 р., лютого 18, Санкт-Петербург. - Лист адвоката Кисво-Печерської лаври, законовчителя Санкт-Петербурзького морського шляхетного корпусу Аггея Колосовського до Печерського архімандрита Зосими Валкевича у справі цензури лаврського друку

Ясне в Богу высокопреподобнъйшій господин отец архимандрит!

Милостивій мой отец и благодьтель!

От 12 генваря почтеннъйшее Вашей святыни писмо и предписанные отцу Златоустовскому архимандриту для пересилки ко мнђ сто рублев денег я 2 дня февраля имъл честь получить, но водки на оніе не покупал и не подносил, как потому что от Вашей святыни ничего к членам о том не писано, без какого выда никто ничего и пріимет, так и для того, что недавно пред сим подносил им присланные от Лавры заидки, которых также нъкоторыи принимать не хотьли. Хотя и писано об них, и я представлял, что Лавра из своих садов всьгда имъет фрукты. Повърьте, что весма здъсь берегутся от взятков не толко в духовных, но и в мирских, однако опосль при подносђ седмичников отважусь поднесть и водку, и мнђ кажется пристойно при таком праздникъ поздравить их, и презентом сим от Лавры свидътелствовать почтение. Вашу же святыню прошу, ежели заблагоразсудите, за получением сего нимало немедля прислать к членам поздравителные о прздникъ Пасхи или отвђтные на посланные [арк. 9 зв.] от их преосвященств чрез нарочного куриера писма, и в них вложить хотя [бы] цъдулки о водкъ. Иначе бо сумнително, чтоб была принята, и опасуюсь, чтоб не пропал кошт лаврскій. Удивляюсь, что мои письма, как цъдулкою обявляти изволите, и по сие время не получены в Лаврђ. И сердечно 
сожалею, естли они пропали, ибо в оных много важного и Лаврђ нужного. Писал да и чрез надежные, кажется, оказіи послал. На сих днях получен в Синодъ из Московской типографіи реестр з сообщеніем нашедшихся в лаврском шестодневђ ошибок, за наступившею масляною и первою недълею поста ничего еще по оному не посльдовало и в представленіи не было. Я тъх ошибок имъю у себе копію, подлинно ошибки, сколь в разсужденіи высочайшей особы важные, столь для Лавры весма опасные, особливо в нынбшнее время. Сего февраля 14 дня в недълю сырную публично при столь, в присутствіи преосвященних Псковского и Тверского такие отец Платон произнес рьчи. Я вам скажу куріозную и удивителную въщь, я сего дня поутру, пришедшій к Его высочеству нечаянно спросил, какой сей день недъли и какое на амбонъ читается евангелие. Он отвђтствовал, недъля сырная и евангелие тотчас сискал, развђрнул [арк. 10] лаврской печати библию, обявил при том, что он два дня уже прочитал библию и нашел в оной погрђшностей - четыреста шестдесят осђм, и оные собственноручными отмьтил почерками, в которых де не токмо ошибки, но и великие с московскою библиею в разумъ имђются несходства. Я могу, сказал отец Платон, испросить ту библию у Его высочества и хорошо б при указђ синодалном оную послать в Лавру с хорошим репримандом - надобно б де, Лаврь, добрую дать финфу и проучить их хорошенко, сами ортографіи не разумђют, а знающего из стороны принять не хотят, и когда на этіи ръчи сказал один посторонный человък, хорошо б им приутвердить указом, чтоб впредь исправно печатали, то сказано в отвђт было то, уже единожды и не дважды это подтверждали, но оны нас не слушают, и не знаю в какую надежду как бы нарочно в противность отменно печатают московским экземплярам, ми принуждены другие принять мъры, в протчем имъю сим быть

Вашея святыни вседостойньйший слуга Аггей.

1770 года 18 февраля

С.-Петербург.

Central State Historical Archive of Ukraine in Kyiv, f. 128, d.1 drukarskyi, c. 161, pp. 9 - 10. The Original.

\section{BIBLIOGRAPHY}

Arhiv Yugo-Zapadnoi Rossii. (1872). Arhiv Yugo-Zapadnoi Rossii, izdavaemyi Komissiei dlia razbora drevnih aktov [Archive of South-West Russia, published by the Commission for the analysis of ancient acts]. Part 1, Vol. 5, Kiev, 666 p. [in Russian]

Bolhovitinov, E. (1826). Opisanie Kievo-Pecherskoi lavry [Description of the Kiev-Pechersk Lavra]. Kiev, Kiev-Pechersk Lavra, 340 p. [in Russian]

Isaievych, YA. (2002). Ukrainske knyhovydannia: vytoky, rozvytok, problemy [Ukrainian book publishing: origins, development, problems]. Lviv: Instytut ukrainoznavstva im. I. Krypiakevycha NAN Ukrainy, 520 p. [in Ukrainian]

Kagamlyk, S. (2005). Kyievo-Pecherska lavra: svit pravoslavnoii dukhovnosti $i$ kultury (XVII - XVIII st.) [The Kyiv Pechersk Lavra: The World of Orthodox Spirituality and Culture (XVIIth - XVIIIth centuries)]. Kyiv: Natsionalnyi Kyievo-Pecherskyi istoryko-kulturnyi zapovidnyk, 552 p. [in Ukrainian]

Kagamlyk, S. (2006). Intelektualne seredovyshche mohyliantsiv u Kyievo-Pecherskii lavri (XVIII st.) [The intellectual environment of Mohyla in the Kiev-Pechersk Lavra (XVIII cent.)]. Kyivska Akademia, 2-3, 177-197. [in Ukrainian]

Kagamlyk, S. (2018). Kyiv-Mohyla Academy Intellectual Space as a Manifestation of Intercultural Communications (on the Basis of the Ukrainian Hierarchs' Epistolary Legacy. Kyiv-Mohyla Humanities Journal, 5, 61-82. [in English] 
Kahanov, I. (1959). Ukrainska knyha kintsia XVI - XVII stolit [The Ukrainian Book of the end of the XVIth and XVIIth centuries]. Kharkiv: Vydavnytstvo knyzhkovoyi palaty, 144 p. [in Ukrainian]

Knyha i drukarstvo na Ukrayini (1964). Knyha i drukarstvo na Ukrayini [Book and printing in Ukraine], ed. M. Popov. Kyiv: Naukova dumka, 313 p. [in Ukrainian]

Kolesnyk, I. (2008). "Intelektualne spivtovarystvo" yak zasib lehitymatsii kulturnoii istorii Ukrainy XIX stolittia [The Intellectual Community as a means of legitimizing the cultural history of Ukraine in the XIXth century]. Ukraiinskyi istorychnyi zhurnal, 1, 169-193. [in Ukrainian]

Maslov, S. (1925). Ukrayins'ka drukovana knyha XVI-XVIII st. [Ukrainian printed book of the XVIth - XVIIIth centuries]. Kyiv: Derzhavne vydavnytstvo Ukrayiny, 76 p. [In Ukrainian]

Ohienko I. (1994). Istoriia ukraiinskoho drukarstva. T. 1: Istorychno-bibliohrafichnyi ohliad ukrainskoho drukarstva XV - XVIII vv. [History of Ukrainian printing. Volume 1: Historical and Bibliographic Review of Ukrainian Printing in the XVth - XVIIIth centuries]. Kyiv: Lybid, $446 \mathrm{p}$. [in Ukrainian]

Opisanie dokumentov i del. (1915). Opisanie dokumentov i del, hraniashchihsia v arhive Sv. Sinoda [Description of documents and files stored in the archives of the Holy Synod]. L (1770), Petrograd, 1150 p. [in Russian]

Opisanie dokumentov i del (1885). Opisanie dokumentov $i$ del, hraniashchihsia $v$ arhive Sv. Sinoda [Description of documents and files stored in the archives of the Holy Synod]. VII (1727), Sankt-Petersburg, 380, 174, 72 pp. [in Russian]

Posokhova, L. (2011). Na perekhresti kultur, tradytsii, epokh. Pravoslavni kolehiumy Ukrayiny naprykintsi XVII - na pochatku XIX st. [At the crossroads of cultures, traditions, eras. Orthodox Colleges of Ukraine in the late XVII and early XIX centuries]. Kharkiv: Kharkivskyi Natsionalnyi Universytet imeni V. N. Karazina, 400 p. [in Ukrainian]

Rossiyskiy Gosudarstvenniy Istoricheskiy arkhiv [Russian State Historical Archive - RSHA]

Stepovyk, D. V. (2001). Istoriia Kyievo-Pecherskoii lavry [History of the Kiev-Pechersk Lavra]. Kyiv: Vydavnychyi viddil Ukraiinskoii Pravoslavnoii Tserkvy Kyiivskoho Patriarkhatu, 558 p. [in Ukrainian]

Titov, F. (1916). Tipografiia Kiievo-Pecherskoi lavry. Istoricheskii ocherk (1606 - 1616 - 1916) [Printing house of the Kiev Pechersk Lavra. Historical sketch (1606 - 1616 - 1916)]. Vol. 1. Kiev: Kiev-Pechersk Lavra, 572 p. [in Russian]

Trotsky, P. (1865). Tipografiia Kievo-Pecherskoi Lavry [Printing house of the Kiev-Pechersk Lavra]. Trudy Kievskoi dukhovnoi akademii. 1865, 5, 6. [in Russian]

Tsentralnyi derzhavnyi istorychnyi archiv Ukrainy, m. Kyiv [Central State Historical Archive of Ukraine in Kyiv - CSHAUK]

The article was received on September 09, 2019. Article recommended for publishing 20/05/2020. 